\title{
Morphological Interference of Javanese in Banyumas Dialect in Purwokerto
}

\author{
Yunilis Andika \\ Descriptive Linguistics Study Program \\ Postgraduate Program, Universitas Sebelas Maret \\ Surakarta, Indonesia \\ Syarif Hidayatullah State Islamic University Jakarta Indonesia \\ yunilisandika@ymail.com \\ Sumarlam \\ Postgraduate Program, Universitas Sebelas Maret \\ Surakarta, Indonesia \\ Syarif Hidayatullah State Islamic University Jakarta Indonesia \\ sumarlamwd@gmail.com \\ Wakit Abdullah \\ Postgraduate Program, Universitas Sebelas Maret \\ Surakarta, Indonesia \\ Syarif Hidayatullah State Islamic University Jakarta Indonesia \\ abdullahwakit@yahoo.com
}

\begin{abstract}
Today, many people in Purwokerto become reluctant to use Javanese in Banyumas dialect in their communication. It is influenced by many immigrants from outside city who settled in Banyumas district to work or study. The decline of the existence of the Banyumas dialect as part of Java language leads to a decline in the ability of the community to use the language itself. As a result, in society, the Javanese language in Banyumas dialect interfered with other languages. This study relates to the interference of bahasa Indonesia to the Javanese in Banyumas dialect. It also aims to identify the morphological interference which founded on the Purwokerto citizen's speech. The data of research obtained by the listening method/ simak method and continued with the SBLC technique (free listening with conversation involvement technique), recording technique, note technique, and indepth interview. The research method used in this research is the padan method with the substitute technique. The results of this research showed that there was morphological interference of Banyumas dialect as Javanese language in Purwokerto. The interference is formed through the process of affixation and reduplication. The affixation processes are divided into three types. They are prefixation, suffixation, and confixation. While on the reduplication, it is founded the complete reduplication process with affixes using the suffixation form. The existence of morphological interference in the Javanese with Banyumas dialect signifies that the language has experienced a language shifting.
\end{abstract}

Keywords-Morphological Interference; Banyumas Dialect; and Purwokerto

\section{INTRODUCTION}

The Javanese in Banyumas dialect is one of the mother languages that is used by the folks in the Banyumas residency, and one of them is Purwokerto. Wedhawati [1] explains that the Javanese in Banyumas dialect is spoken by the people in
Banyumas residency which covers the area of Purwokerto, Purbalingga, Cilacap, Banjarnegara, also several parts of the Pekalongan and Kedu (Kebumen district) residencies. The use of this dialect can be found on the daily basis such as; in the family, in the social life, in the work field, in the religion, etc. In its use, not only the Banyumas Javanese dialect that is used in the communication, but also other languages such as Bahasa Indonesia as the national language. The use of these two languages is caused by the languages intercourse which is known as bilingualism.

The language experts have long believed that there is an influence from the first language to the second language. This named as the language transfer, or also known as the language interference. It happens when the speakers of the Javanese in Banyumas dialect use this dialect with the Bahasa Indonesia alternately. According to Wenreich [2], the interference is considered as the deviation from the language norms. It happens to the language speakers as the effect from the use of more than one languages as the result of the bilingualism.

These days, Purwokerto folks begin to reluctant to communicate using the Javanese in Banyumas dialect. The existence degradation of this dialect causes the degression in people's ability to use it. This is affected by a lot of the newcomers outside the Purwokerto who stay there to work or to study. The local people use Bahasa Indonesia in the daily basis to communicate with them so that often the use of it is carried away into the family. As a result, there are many Javanese in Banyumas dialect speeches that are interfered with other languages. It begins to be replaced with the Bahasa Indonesia as the national language and also the English as the international language which is mandatory to be mastered. These languages often shift the existence of the Javanese in 
Banyumas dialect.

The movement of the Javanese in Banyumas dialect into the Bahasa Indonesia by the original speakers leads to the degenerate of the people's capability in Purwokerto to use it. With the declining of this language ability, it makes the form of this dialect mixed with the Bahasa Indonesia and also the foreign languages. For example, the young families in Purwokerto society will mostly use Bahasa Indonesia to talk to their children rather than to speak in their own dialect (the Javanese in Banyumas dialect). This leads to the emerging of the Javanese in Banyumas dialect speeches that are interfered with other languages. On the process of it, the use of the language is not completely following the rule, But, it encounters the degression due to the influence of the other languages. This interference of the Javanese in Banyumas dialect itself can be found in its phonology, its vocabulary or lexical, its grammatical (morphology and syntax), and its semantics. In this paper, the object of the study is the Javanese in Banyumas dialect; with looking at how the interference formed in it on its morphological level.

The study about interference had been conducted by some researchers. The research about the interference of the Javanese in Banyumas dialect in the family sphere had been done by Chusmeru [3] and Mardikantoro [4]. These studies become interesting because it is still rarely done; as the family is the place where a language is introduced, taught, and used to a child. The research was done to find the people's speech loyalty to the use of the Javanese in Banyumas dialect. The study research setting was at the Brebes city and also at the housing. However, the use of the dialect in these locations is also concerned as it could show a less valid result. Generally, the languages used in Brebes are the mixture of Javanese in Banyumas dialect and Sundanese. The setting of the study which was in the housing also became less valid result since the people who lived there tended to live individually and less communicated on the daily basis. Furthermore, in some region, since housing is an artificial region, it is better to choose a village or a city which truly represents as the setting of the study. The Javanese study was also done by Maryam [5]. The purpose of it was to find the passive form pattern in Banyumas-Javanese. In her study, it used the morphological approach.

Based on those reasons, the interference of bahasa Indonesia to the Javanese in Banyumas dialect on the family domain in Purwokerto was intensively observed in this study. Moreover, bahasa Indonesia was mastered by the Purwokerto citizen as its role as the national language. Therefore, there was a stigma which mentioned that there was an influence of it on the Javanese in Banyumas dialect. This became another reason for the researcher to conduct the research. However, how much this influence was, especially for the morphological interference still had not known for sure yet. Therefore, it was necessary to conduct a study to discover it.

There are already several studies which focused on the language interference. However, the study in the sociolinguistic field related to morphological interference in the Javanese in Banyumas dialect in Purwokerto is still possible to be done as there are some differences with the previous ones. Even it focuses on the family level, however, this study would try to expose the phenomenon of Bahasa Indonesia interference to the Javanese in Banyumas dialect in Purwokerto at the morphological level.

Based on the prior discussion, the formulation of this study is on how the morphological interference form in the Javanese in Banyumas dialect in Purwokerto. This research is to describe it in its (1) affixation and (2) reduplication aspects.

\section{METHODS}

This study uses the sociolinguistics with the descriptive qualitative approach. The location of this study is in four districts in Purwokerto. They are South Purwokerto, West Purwokerto, East Purwokerto, and North Purwokerto districts. Purwokerto is selected as a location of the research due to the fact that there are many newcomers who stayed in this city. The varieties on their background included their languages make the native citizen of Purwokerto have to adapt their ways in communication. The diversity of languages is also one of the causes of the language interference, especially the morphological interference on the Javanese in Banyumas dialect.

Santosa [6] said that there are two types of data namely primary data and secondary data. The primary data is taken from the conversation records which have the morphological interference on the Purwokerto citizen's speech. Furthermore, for the secondary data is in the form of questionnaire, books, articles, theses, and other sources which are relevant to this study. The source of the study is the conversation recording of the family who speaks in Banyumas dialect and interfered by Bahasa Indonesia. The subject of this research is the family domiciled in Purwokerto city, is the local resident of Purwokerto, use the Javanese in Banyumas dialect in the family daily basis, also didn't lack in physically nor mentally.

The data of research obtained by the listening method/ simak method and continued with the SBLC technique (free listening with conversation involvement technique), recording technique, note technique, and indepth interview [7]. Next, the data is analyzed using the padan method with the substitute technique.

\section{RESULT AND DISCUSSION}

From the Javanese in Banyumas dialect morphological system, the interference can occur on the phonological, lexical, grammatical (morphological \& syntax), also on the word meaning (semantics). The findings of this research show that there are some morphological interferences from Bahasa Indonesia to the Javanese in Banyumas dialect from the affixation and reduplication aspects. The explanation as follows.

\section{The Morphological Interference on Bahasa Jawa in Banyumas Dialect Based on the Affixation Aspect}


Affixation is a process of adding a morpheme to the word base form. It can be divided into several types. They are prefixation, infixation, suffixation, and confixation.

\section{a. Prefixation}

Prefixation is a morphological process where a bound morpheme is placed in front of a word to change its meaning. Along with it, Verhaar [8] states that prefix is an affix which is added on the left side of the word stem. This happens in the process called as prefixation. The affixes used are called as prefixes. There are several morphological interferences in the form of prefixation founded in this study. It is used on the Javanese in the Banyumas dialect which can be seen in the data below.

(1) A: Wingi tes sekang ngendi mba?

\section{B: Sekang Tamansari \\ A: Plesir bae loh. Ati-ati ya mbok ditabok wong diajak metu.}

The word diajak $(d i+$ ajak $)$ is interfered as the stem word ajak is the Bahasa Indonesia's morpheme. On the Javanese in Banyumas dialect, the morpheme ajak is also used. But, there is a difference in pronouncing the word. It will be heard more like the word ajek. The stem word of ajek then gets the prefix $\{\mathrm{di}-\}$, becomes diajek $(d i+$ ajek $)$, and if it is pronounced becomes dijek $(d i-+j e k)$ or dejek $(d e-+j e k)$. Another form of it is on the word ditransfer or detransfer which gets the prefix $\{$ di-/de- $\}$. Also, on the prefix attachment $\{$ tok- $\}$ on the word tekunduh.

\section{b. Suffixation}

Suffixation is a morphological process where a bound morpheme is placed behind the word stem. This is along with the theory which is stated by Verhaar [8]. He argues that suffixes are the affixes added into the right side of a base word in a process called as suffixation. This study finding shows the morphological interference from Bahasa Indonesia to the Javanese in Banyumas dialect based on its suffixation process. It can be seen as follows.

\section{(2) A: Mas Bayu lagi neng ndi sih siki?}

\section{B: Lagi neng nggone mas Priyo, kanca kenthele.}

The words kanca kenthele are formed from the stem word kanca kenthel 'teman dekat/sahabat', with the addition of the sufix $\{-\mathrm{e}\}$. The pattern used in those words follows the morphological pattern on the words 'teman dekat' in Bahasa Indonesia. It is formed from the (kanca kenthel $+-e)$. The terms kanca kenthel is just known by the people through a popular song. From there, it starts to be used and shifts the common term before, which is kanca perek. Other examples of suffixation are on the word haruse, namane, and PR-e. They got the suffix $\{-\mathrm{e}\}$. Also, on the word malmingan which got the suffix $\{-a n\}$. These words have the suffixes at the end of the words stem.

c. Confixation
Chaer [9] argues that confixes are affixes which attached on the left and right sides of the stem word at the same time, as they are one affix. The affix which placed between its stem is called as confix. There are several morphological interference from Bahasa Indonesia to the Javanese in Banyumas dialect with confixation process as follows.

\section{(3) A : Hahaha.. Tangi turu kaya mbah dukun deneng? \\ B: Dukun gundulmu, Mad. Hahaha.} Tapi tekperhatikna sih masuk akal. Hahaha.

The word tekperhatikna (perhatian + tek-/-na) is interfered as the stem 'perhatian' is the Bahasa Indonesia's morpheme. On the Javanese in Banyumas dialect there is also a similar morpheme with that. It is deleng that becomes tekdelengna (deleng + tek-/-na).

Based on the findings above, it can be concluded that on the morphological interference from Bahasa Indonesia to the Javanese in Banyumas dialect on the family in Purwokerto, the researcher only could find the morphological interferences in the form of prefixes, suffixes, and confixes. She did not found the morphological interference in the form of infix from the Purwokerto citizen's speech.

\section{The Morphological Interference on Bahasa Jawa in Banyumas Dialect Based on the Reduplication Aspect}

This study shows that there is a morphological interference in the form of reduplication or repetition on the Purwokerto citizen speech on the family sphere. The reduplication can be seen on the following data.

\section{(4) A: PR-e Kakak nopo? \\ B : Tambah-tambahan \\ A: Ples-plesan?}

Tambah-tambahan nopo pengurangan?

Based on the data above, the reduplication morphological interference is on the word tambah-tambahan. This word comes from the stem tambah which is repeated completely into the word tambah-tambahan, with the attachement of suffix $\{-a n\}$.

From that explanation, the researcher groups the reduplication type on the word tambah-tambahan into the intact reduplication with affixes using the suffixation process group. The grouping itself is based on the theory from Abdullah and Handayani [10], who divide the reduplication into three. They are intact reduplication with affixes (prefixes, infixes, suffixes, and confixes), intact reduplication without affixes and partial reduplication.

Based on the result above, it can be concluded that Purwokerto as the district capital of Banyumas also as the administration center at once makes it as the city for immigrants. The varieties of the newcomers' background along with their various kind of languages make the local citizen of Purwokerto also have to adapt themselves in the communication. Therefore, no wonder if they are able to speak 
well in Bahasa Indonesia outside the house, without abandoning their native language which is the Javanese in Banyumas dialect. It also the same language that they use to communicate with their family in their home. However, it leads to a new language phenomenon, the interference.

This interference on the Javanese in Banyumas dialect mixes with the Bahasa Indonesia on the Purwokerto residents speech. They tend to follow the morphological pattern on Bahasa Indonesia which can be found in several speeches. The way they done this are by taking the morphological elements of bahasa Indonesia and uses it in the Javanese in Banyumas dialect. It leads to the morphological interefernce. It also includes the affixation process, which are prefixes, suffixes, and confixes, also reduplication. However, the researcher did not find the interference in the infixes form on the family domain speech. This morphological interference on the Javanese in Banyumas dialect shows that this language has shifted.

\section{CONCLUSION}

The explanation above shows that the Javanese in Banyumas dialect on the family at Purwokerto is heavily influenced with bahasa Indonesia. This kind of interfence can be categorized as the deviation on the language norms.

The interference phenomenon is highly possible to happen in a society which has more than one language. Even the Javanese in Banyumas dialect has experienced it, in fact, the speakers of it in Purwokerto still have a high loyalty to their native language. It shows on the statements from the interviewees which says the importance to conserve this language.

So, it needs the people awareness especially families in Purwokerto to get used to this language. Especially in the family, they need to adapt themselves and use it in the communication at home, because the family is the first place where a language is introduced and taught to a child. This is also expected to be the solution to minimalize the occurrence of interference, especially on the Javanese in Banyumas dialect in Purwokerto.

\section{REFERENCES}

[1] Wedhawati, Tata Bahasa Jawa Mutakhir. Yogyakarta: Kanisius, 2006.

[2] I. N. Suandi, Sosiolinguistik. Yogyakarta: Graha Ilmu, 2014.

[3] W. E. R. Chusmeru, "Penggunaan Bahasa Jawa dialek Banyumasan dalam Keluarga di Perumahan Karang Asri Kelurahan Karangrau Kecamatan Sokaraja (Studi Etnografi tentang Pola Komunikasi Bahasa Jawa dialek Banyumasan)". ActadiurnA, vol. 9 no. 2, pp. 71-79, 2013.
[4] H. B. Mardikantoro, "Pergeseran Bahasa Jawa dalam Ranah Keluarga pada Masyarakat Multibahasa di Wilayah Kabupaten Brebes". Humaniora, vol. 19, pp. 43-51, 2007.

[5] S. Maryam, "Analisis Morfologi Bentuk Pasif Bahasa Jawa dialek Banyumas". Jurnal Ilmiah Program Studi Pendidikan Bahasa Indonesia Universitas Muhammadiyah Jember, vol. 2, no. 2, pp. 73-81, 2016.

[6] R. Santosa, Metode Penelitian Kualitatif Kebahasaan. Surakarta: UNS Press, 2017.

[7] Mahsun, Metode Penelitian Bahasa. Jakarta: PT Raja Grafindo Persada, 2005.

[8] J. W. M. Verhaar, Asas-Asas Linguistik Umum. Yogyakarta: Gadjah Mada University Press, 2004.

[9] A. Chaer, Morfologi Bahasa Indonesia (Pendekatan Proses). Jakarta: Rineka Cipta, 2008.

[10] W. Abdullah, and S. L. Handayani, Bahasa Jawa Kuna: Sejarah, Sruktur, dan Leksikonnya. Surakarta: Jurusan Sastra Daerah UNS, 2007. 